\title{
An African Pioneer Comes of Age: Evolution of Information and Communication Technologies in Uganda
}

\author{
Patience Akpan-Obong \\ Arizona State University, \\ Phoenix, AZ, USA \\ patience.akpan@asu.edu \\ Kibily D. Samake \\ Louisiana State University, \\ Baton Rouge, LA, USA
}

\author{
Carlos A. Thomas \\ Southern University and \\ A\&M College, Baton Rouge, \\ LA, USA
}

loshead1285@yahoo.com

\author{
Moses Niwe \\ Stockholm University/Royal \\ Institute of Technology, \\ Stockholm, Sweden
}

mosesniwe@gmail.com
ksamak1@Isu.edu

\section{Victor W. Mbarika \\ Southern University and A\&M College, Baton Rouge, LA, USA}

\section{victor@mbarika.com}

\begin{abstract}
Material published as part of this publication, either on-line or in print, is copyrighted by the Informing Science Institute. Permission to make digital or paper copy of part or all of these works for personal or classroom use is granted without fee provided that the copies are not made or distributed for profit or commercial advantage AND that copies 1) bear this notice in full and 2) give the full citation on the first page. It is permissible to abstract these works so long as credit is given. To copy in all other cases or to republish or to post on a server or to redistribute to lists requires specific permission and payment of a fee. Contact 0HPublisher@InformingScience.org to request redistribution permission.
\end{abstract}

The Internet story in Uganda dates back to April 1993 with associations to a Fidonet node at Makerere University, the largest institution of higher education in the country. E-mail services in private companies became accessible in August 1994, making Uganda one of the first countries in sub-Saharan Africa to gain full Internet connection. This paper presents an overview of developments in the Internet sector since then. The Global diffusion of the Internet (GDI) framework is used to assess the country's Internet diffusion. The framework provides an overview of the state of the Internet while identifying specific ways in which the Internet has been used in the war-torn northern region of Uganda. A case study of the efforts of two nongovernmental organizations to provide Internet connectivity in Internally Displaced Persons camps demonstrates the point that the Internet can serve as a useful tool for giving a "voice" to people in war zones in a process that can potentially reduce internal conflicts.

Keywords: Internet diffusion, Uganda, conflict, development, information and communication technology 


\section{Introduction}

A specific international discourse dominated development theory and practice in much of the 1990s. The issues were framed around the utility of information and communication technologies (ICTs) for socioeconomic development. This attracted the attention of many developing countries especially in Africa still reeling from the effects of the "lost decade" of the 1980s and structural adjustment programs. Also, there was continental interest in the prospects of information and communication technologies for development (ICT4D). This was expressed by organizations such as the United Nations Economic Commission for Africa (UNECA) and the New Partnership for African Development (NEPAD). Unlike many countries in Africa, Uganda responded to the ICT4D debates early on. However, while it was a pioneer by getting a head start through its various initiatives and programs, it was not until 2005 that it finally articulated a systematic policy on ICTs as fundamental tools for socioeconomic development. The country began with the Ugandan Communication Act, enacted in 1997. It was a response to the 1996 mandate of the UNECAsponsored African Information Society Initiatives (AISI) for African countries to formulate policies that would accelerate their advancement toward the global information society. For many countries, the interest in creating an information society immediately led to the deregulation of the telecommunication sector. Policies on the telecommunication also provided oversight to the Internet sector at the initial stage. The creation of an appropriate policy framework for both the telecommunication and Internet sectors was the central purpose of the Ugandan Communication Act. The Act was itself implemented through the highly influential Ugandan Communications Commission (UCC).

Uganda presents an interesting case for an examination of the application of ICTs for development in an African country for two major reasons. First, the country was one of the earliest to respond to the discourse that made the connection between ICTs and socioeconomic development. While some countries were still trying to understand the substance of the debates, the Ugandan government had already enacted the Communication Act to provide "a framework for the development of a telecommunication sector in the country" (UNECA, 2009). That act unwittingly set a model for ICT policymaking in other African countries where telecommunication policies became the proxies of state interventions in the sector.

An important part of the Communication Act was the role that it assigned to the Ugandan Communications Commission (UCC) The UCC implements the provisions of the Ugandan Communication Act by controlling and promoting developments in the partially deregulated telecommunication sector (broadly defined to include all ICTs). The Commission's major mandate was the integration of universal access provisions in the delivery of communication and information services in the country. The Commission works to "improve communication services generally and to ensure equitable distribution of services throughout the country" (Ugandan Communications Commission [UCC], 2008, p. 10). Another aspect of its mandate was the establishment of the Rural Communication Development Fund (RCDF) which was expected to prevail on telecommunication operators to provide $2.5 \%$ of their growth revenues for rural communication services.

The evolution of ICTs in Uganda and the gradual journey toward an information society - at least going by the standards of the International Telecommunication Union (ITU) - raise important issues for research, some of which we explore in this article. Arguably, there is nothing significantly remarkable about the growth of ICTs in Uganda. Yet there is a sense of measured and progressive steps toward the future as the different technologies continue to diffuse widely over the years. Our study examines this spread of ICTs in Uganda with an emphasis on Internet connectivity and the manner in which access to the Internet has become a coping mechanism, if not conflict resolution strategy, in war-torn Northern Uganda. 
The article begins with a discussion of the telecommunication and ICT policy environment and the second section concentrates on the Internet. While computers and telephones feature fully in the debates about the potentials of ICTs for development, the Internet perhaps has the most power to achieve crucial socioeconomic goals as well as address ethnic tensions. Besides, the Internet is a computer network that can be integrated with other technologies and information systems. In examining the Internet, therefore, one is essentially addressing other related technologies such as the telephone, cell phone, and computer-based information systems. Also, the Internet, rather than other technologies, has been adopted as the communication channel of choice by organizations and individuals working with families in the Internally Displaced Persons of Northern Uganda. In the last section, we present a descriptive analysis of Internet adoption and usage by two nongovernmental organizations, BOSCO and Inveneo, in internally displaced persons camps in Northern Uganda, a hotbed of ethnic conflicts in the country.

\section{Methodology}

We adopt the Global Diffusion of the Internet Framework (GDIF) for the analysis of the status of the Internet in Uganda. The framework, developed in 1996 by Peter Wolcott and his colleagues in the Mosaic Group, assesses a country's Internet diffusion through six dimensions and two determinants. GDIF has been used in the study of the Internet in at least 40 countries, such as China (Foster \& Goodman, 2000), Togo (Bernstein \& Goodman, 2005) and Mexico (Thomasson, Foster, \& Press, 2002). The GDIF dimensions are: pervasiveness, geographic dispersion, sectoral absorption, connectivity and organizational infrastructure, and sophistication of use. With each dimension, a score that ranges between 0 and 4 is given based on a group of fixed assessment criteria (Wolcott, Press, McHenry, Goodman, \& Foster, 2001).

GDIF is distinctive in that it has two general emphases. Firstly, it considers the absolute degree to which the Internet is being used (as measured in connectivity and organizational infrastructure, and sophistication of use). Secondly, it has a strong diffusion focus, allowing the examination of how widely the Internet is used geographically (geographic dispersion), among individuals (pervasiveness) and organizations (sectoral absorption). Though the framework focuses on Internet diffusion, we have also applied it to computers and telephones given the integrated nature of these ICTs.

Data for the study are generated from various sources including official Ugandan government documents. But mostly, we rely on materials from international organizations such as the ITU and the World Bank in combination with information obtained from websites of Ugandan agencies and service providers. While service providers have been known to exaggerate their performance and subscription numbers to emphasize greater popularity than the competition, we must inevitably utilize their internally collected data given the general paucity of independently generated data on ICTs in Africa.

\section{Uganda}

Uganda is a landlocked country located in East Africa, bordering the countries of Kenya, Tanzania, Zaire, Sudan, and Rwanda. (See map in Figure 1.) It covers an area of approximately 236.000 square kilometers populated by 31.66 million people in 2009 (International Telecommunications Union [ITU], 2009a). The majority of Ugandans live in the rural areas, especially in the highly populated southern region. The annual population growth rate for 2004 was estimated at four percent (ITU, 2009a). This growth rate was expected to have a significant impact on the proportion of the population living in rural areas, with a projected decrease from $84 \%$ to $62 \%$ and a corresponding increase in urban dwellers from 16\% to 38\%, by 2009 (Uganda Bureau of Statistics, 2006). Kampala, with a population of $1,208,544$, is the capital. The country is governed by the 1995 ratified constitution and headed by an executive president (U.S. Department of State, 
2009). The current president is Yoweri Museveni. He has held the position since 1986 (State House Republic of Uganda, 2009).

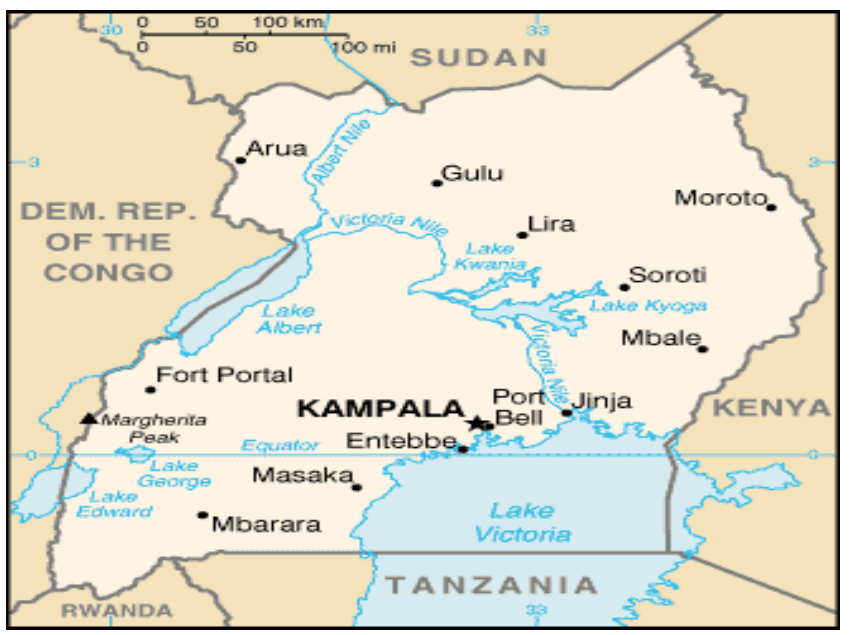

Figure 1. Map of Uganda Source: World Fact Book, 2009

Uganda's economy relies heavily on the agricultural sector, much like those of many African countries. Since the country's independence in 1962 from Britain, agricultural exports have made up about $80 \%$ of the country's economy, with coffee accounting for much of the country's export revenues (World Fact Book, 2009). Other major agricultural activities are cotton, tea, and tobacco. At the domestic level, 70\% of the people's livelihood comes from livestock and fishing. Expectedly, a majority of Ugandans (88\%) are involved in agriculture with services accounting for $13 \%$ of the labor force. Industry lags behind at 5\% (World Fact Book, 2009).

In terms of conflicts, Uganda typifies many countries on the continent. To start with, ethnic tensions plunged the country into the dictatorship of Idi Amin (1971-1979) who virtually destroyed Uganda through mass execution and murders. It is estimated that as many as 500,000 Ugandans were killed during Amin's seven-year regime ("Idi Amin," 2009). Secondly, while there has not been any dictator in other parts of Africa as murderous as Idi Amin, the continent continues to be dotted by ethnic conflicts, wars, and leaders whose priorities are not the people. A persistent war has been waged for 23 years in the northern region by the Lord's Resistance Army against the government of Yoweri Museveni, himself a former rebel leader (or freedom fighter). It is in this region that a lot of Internet activities have occurred. Many Ugandans living in more than 100 Internally Displaced Persons camps in the northern region have been provided with Internet access as a medium through which they can tell their personal stories about the war. In addition, the technology and related peripherals have also been utilized in the process of reconciliation and reconstruction in the northern region. While the provision of Internet access in the displaced persons' camps is deliberately aimed at facilitating communication, it is also expected that a successful utilization of the technology (as well as other ICTs) in many aspects of Uganda's socioeconomic process is likely to spill over to other sectors in ways likely to reduce ethnic conflicts.

\section{ICT Infrastructure in Uganda}

In many African countries, government policies focused on telecommunication narrowly conceptualized as telephony. However, agencies such as the UCC and Nigeria's National Communication Commission, set up to implement policies in the telephony sector, also provided oversight for related policies aimed at promoting the development of other ICTs in the countries. It was not until 2005 that the ICT policy in Uganda was formulated. This led to the establishment of the 
Ministry of Information and Communication Technologies in 2006. The ministry incorporates the mandates of the Communications Act, but it also creates a space for the articulation of policies and programs that increased access to the other technologies of ICTs such as computer and Internet.

Again, as in many developing countries, Internet access occurred initially in the universities. In Uganda, the premier Makerere University, founded in Kampala in 1922 (the oldest university in East Africa) was also one of the early pioneers of Internet usage in Uganda. Indeed, one of the original references to the Internet in Uganda shows the existence of a Fidonet (a network for exchanging e-mails) node at Makerere University as early as April 1993 (Mwesige, 2004). It subsequently "embarked on an ambitious project, with the support of external partners, to integrate information and communication technology (ICT) in all its functions as one of the critical elements of its strategic plan" (Makerere University, 2008). A central goal of the plan was to provide university-wide access to ICTs and utilization of the technologies to "enhance the position of Makerere University as a centre of academic excellence and its contribution to the sustainable development of society" (Makerere University, 2008).

The university is probably the only one in the region with an articulated ICT Policy with vision goals that include the deployment of ICTs in "all areas of education and research through creating technical and organizational preconditions" (Makerere University, 2008). As well, the policy requires that "all students, academic staff, administrative and support staff, and managerial staff are trained on a continuing basis to equip them with the requisite skills to fully exploit the ICT environment in their different functions" (Makerere University, 2008). Makerere University in Kampala was on the front line in the articulation of ICTs as enhancing research and education with the ultimate goal of contributing to the macroeconomic sector. It remains a model of ICT usage in a university campus on the continent. It is perhaps not a coincidence that Kampala leads the country in Internet usage in the country at 53\% (Wahome, 2009).

Uganda has experienced a rapid growth in ICT applications, particularly the Internet. A ministerial policy statement on telecommunication indicated a "substantial growth in the usage of Internet services as evidenced by the proliferation of Internet Service Providers (ISPs) and Internet cafés with consequent increases in numbers of subscribers and users. There has also been increased use of the Internet in the areas of education, medicine and business" (Gita \& IkojaOdong, 2003). The government has adopted policies to enhance the country's ICT capacity through the establishment of government subsidies, to encourage companies like the South African-based Mobile Telecom Network (MTN) to invest in ICT infrastructures in the less profitable rural communities. The country's minister for ICT, Alintuma Nsambu, has been a strong advocate of liberalization arguing that "full liberalization of the telecoms sector was extremely important for any nation's economy (because) it provides consumers with lower prices, better customer service and faster Internet access" ("Ugandan Minister Knocks...," 2008).

Policymakers approach the ICT sector from the perspective that government's role should be to support private companies by removing any bottlenecks. According to Nsambu, this role includes discouraging bribe-taking by officials and establishing mechanisms for accelerated clearance of imported ICT equipment by customs officials. "Liberalizing the telecom sector means discouraging monopolies or duopolies," he also said (as quoted in "Ugandan Minister Knocks...," 2008). Perhaps as a consequence of this, both the fixed line and mobile telephone networks have experienced a five-fold increase in the total number of users (Table 1). The growth has also impacted Internet diffusion. By the end of 2002, there were 6,500 Internet subscribers in the country. (The indicator of "Internet subscribers" is different from "Internet users." According to ITU (2009b), "Internet subscribers refer to the number of dial-up, leased line and broadband Internet subscribers... Internet Users is based on nationally reported data" differing in the age groups covered and frequency of usage.) In 2007, the subscription rate had more than doubled rising to 15,000 at the 
penetration level of $0.05 \%$ of the population (ITU, 2009a). By June 2009, there were 2.5 million Internet users in Uganda with a 7.7\% population penetration level. These numbers place Uganda in the seventh position on the table of top ten Internet-penetrated countries in Africa. Nigeria is in the first position while South Africa is fourth (Internet World Stats, 2009).

The relatively rapid diffusion of Internet usage was also connected with the entry of Internet service providers (ISPs) into the market, transforming the landscape from the humble beginnings of store-and-forward connectivity that characterized the emergence of the Internet in many African countries. The first private ISP in Uganda was InfoMail (IMUL) which established a Very Small Aperture Terminal (VSAT) service via an InterSputnik satellite to the United States. The company later merged with the country's second ISP, Starcom, an affiliate of U.S.-based Starlight Communications (United Nations Economic Commission for Africa [UNECA], 2009). The merger between InfoMail and Starcom led to a new ISP, Infocom now one of the leading ISPs in the country.

Table 1. ICT Infrastructure in Uganda

\begin{tabular}{|c|c|c|c|}
\hline Service Providers & Number & Communication & Number \\
\hline \multirow[b]{2}{*}{ National Telephone Operators } & \multirow[b]{2}{*}{2} & Fixed Phone Lines & $162,300(0.53 \%$ \\
\hline & & Telephone subscribers & $\begin{array}{l}4.35 \text { million } \\
\text { (14.11\% of the } \\
\text { population) }\end{array}$ \\
\hline National Postal Operators & 1 & Pay Phone & 10,925 \\
\hline Mobile Telephone Operators & 22 & Mobile Cellular Subscribers & $\begin{array}{l}4.19 \text { million } \\
\text { (13.58\% of the } \\
\text { population) }\end{array}$ \\
\hline Internet Service Providers & 25 & & \\
\hline $\begin{array}{l}\text { VSAT International Data Gate- } \\
\text { ways }\end{array}$ & 8 & & \\
\hline Private FM Radio Stations & 145 & & \\
\hline Private Television Stations & 34 & & \\
\hline Courier Services & 25 & & \\
\hline
\end{tabular}

Many legislative measures have followed the enactment of the Ugandan Communications Act of 1997. For instance, several cyber-related legislations were presented to the Ugandan Parliament in 2008. Also, the Uganda Law Reform drafted and presented four ICT-related bills to the federal government in 2008 (Kazooba, 2008) The bills were: the Electronic Transactions Bill, the Electronic Signature Bill (that would require a source of an e-mail communication to sign digitally as a way of authenticity), the National Information Technology Authority Bill, and the Computer Misuse Bill (Kazooba, 2008).

\section{Expansion of ICT landscape}

By April 2001, the UCC had licensed more than 15 ISPs. (There are currently 25 ISPs in the country.) The leading ISPs include Infocom, BushNet, AfricaOnline, and One2net. As was the case in Nigeria in the mobile telephony sector, the initial ISPs in Uganda obtained a five-year 
exclusivity period before more actors were allowed into the market (Akpan-Obong \& Foster, 2007). This was to ensure that the early ISPs recovered their investments before competition became steep. Following the end of the exclusivity period, the cost of Internet access dropped as more providers entered the market with newer and cheaper technologies - such as the VSAT, which facilitated the expansion of Internet access to rural Uganda.

VSATs also fostered the rise of Internet cafés (or cyber cafés) that provide an inexpensive platform from which many users - particularly those living in the rural areas - access the Internet. According to a survey conducted by UCC in 2005 in Kampala and four other major towns (Jinja, Mbale, Lira, and Mbarara), a majority of Ugandans (80\%) access the Internet in cyber cafés (UCC, 2006a). The growth of clientele has also led to a rise in the number of cyber cafés that now offer more sophisticated services beyond basic emailing, though several studies indicate that emailing remains the most common activity in a cyber café. Cyber cafés have become hubs of ecommerce and recreation including computer training and printing. It is now common to find urban-dwelling Ugandans going to a cyber café to book for railway and airline tickets, shop for books and gifts, search and apply for jobs. According to observations in some cyber cafés in Kampala by one of the authors of this article, business and pleasure intersect in cyber cafés. Some clients, mostly in the 18-25 age group, go to cyber cafés just to meet and make friends. As one observer put it, "there isn't a drop of coffee in cyber cafés but there is a lot of socializing," especially across genders.

The growth, popularity, and multipurpose nature of cyber cafés have turned the business into a success even as owners engage in price-wars and intense advertising to compete for increasingly discriminating and literate clientele. Some of the smaller cafés have at least 80 clients daily while the larger ones can draw in as many as 250 (Mwesige, 2004). Cyber cafés and other communitybased Internet centers may have succeeded in bringing the technology closer to Ugandans in ways that might contribute to closing the global digital divide. However, this does not resolve the problem of the internal digital divide. As we've already seen, while Internet diffusion has been relatively rapid in the country relative to other countries on the continent, less than eight percent of the population are Internet users.

Cyber cafés do extend access to more Ugandans, however the typical cyber café user in Uganda is not an 'ordinary' citizen but is already privileged in other socioeconomic factors such as educational and income levels (Mwesige, 2004, p. 989). Another concern is that "most Internet consumers are interested in social networking sites" (Wahome, 2009) and neglecting economic activities. Therefore, the assumption that usage of ICT would translate to economic development might be challenged. However, Internet usage for social networking might yield dividends in other areas, as will be discussed later in the section on the use of the Internet in conflict environments.

\section{Initiatives of ICTs for Development}

Uganda seems to have moved from developing ICT legislations and infrastructure to exploration of viable approaches to the integration of the technologies in other sectors of the economy. The country's stated commitment to harness ICTs for socioeconomic development has resulted in the establishment of various poverty-reducing and sustainable development projects such as the Poverty Eradication Action Plan (PEAP), Plan for Modernization of Agriculture (PMA), Universal Primary Education (UPE), and Vision 2025 (The Republic of Uganda, 2003). These activities were ostensibly premised on the understanding that availability of information at all societal levels (national, district, and sub-counties) would not only facilitate national development programs aimed at poverty eradication but would also advance efforts at decentralization of governance. For instance, open communication channels and free-flow of information were expected to foster some form of open-source political process and facilitate the identification and fulfillment of the 
needs of various interest groups in the country. According to new indicators released by the International Telecommunications Union (ITU) in 2009, the country's ICT use sub-index - measured by Internet user penetration, fixed broadband penetration, and mobile broadband penetration rose in ranking from 132 in 2002 to 126 in 2007. Its access sub-index also increased from 0.79 in 2002 to 1.30 and moved the country from the $150^{\text {th }}$ position to $142^{\text {nd }}$ in ranking. The access subindex is measured by five indicators: fixed line penetration, mobile cellular penetration, international Internet bandwidth per Internet user, the proportion of households with computers and the proportion of households with Internet access (ITU, 2009b).

\section{Diffusion of the Internet in Uganda}

Follow the findings resulting from our investigation of the diffusion of the Internet in Uganda from the perspective of GDIF dimensions - pervasiveness, geographic dispersion, sectoral absorption, connectivity and organizational infrastructure, and sophistication of use.

\section{Pervasiveness}

Pervasiveness is a measure based on users per capita and the degree to which non-technicians are using the Internet. Table 2 illustrates the number of Internet users in Uganda between 2003 and 2008. As can be seen, Internet usage in the country has grown tremendously with the latest statistics indicating a rise from 125,000 in 2003 to 2.5 million users by June 2009 . This figure represents $7.7 \%$ of the population, compared to $0.47 \%$ in 2003 (ITU, 2009a).

\begin{tabular}{|c|c|}
\hline \multicolumn{2}{|c|}{ Table 2. Internet Usage in Uganda } \\
\hline$\underline{\text { Year }}$ & $\underline{\text { Users }}$ \\
\hline 2003 & 125,000 \\
\hline 2004 & 200,000 \\
\hline 2005 & 500,000 \\
\hline 2006 & 1.5 million \\
\hline 2007 & 2 million \\
\hline 2008 & 2.5 million \\
\hline Source: ITU, 2009a & \\
\hline
\end{tabular}

Uganda is therefore on Level 3 (Common) in the GDI pervasiveness dimension (Table 3). More than one percent of Ugandans use the Internet, according to the criteria of usage adopted by the ITU.

\begin{tabular}{|l|l|}
\hline \multicolumn{2}{|c|}{ Table 3. Pervasiveness of the Internet in Uganda } \\
\hline Level 0 & $\begin{array}{l}\text { Non-existent: The Internet does not exist in a viable form in this country. No } \\
\text { computers with international IP connections are located within the country. } \\
\text { There may be some Internet users in the country; however they obtain a con- } \\
\text { nection via an international telephone call to a foreign ISP. }\end{array}$ \\
\hline Level 1 & $\begin{array}{l}\text { Embryonic: The ratio of users per capita is on the order of magnitude of less } \\
\text { than one in a thousand (less than } 0.1 \%) .\end{array}$ \\
\hline Level 2 & $\begin{array}{l}\text { Established: The ratio of Internet users per capita is on the order of magnitude } \\
\text { of at least one in a thousand (0.1\% or greater). }\end{array}$ \\
\hline Level 3 & $\begin{array}{l}\text { Common: The ratio of Internet users per capita is on the order of magnitude of } \\
\text { at least one in a hundred (1\% or greater). }\end{array}$ \\
\hline Level 4 & $\begin{array}{l}\text { Pervasive: The Internet is pervasive. The ratio of Internet users per capita is } \\
\text { on the order of magnitude of at least one in ten (10\% or greater). }\end{array}$ \\
\hline
\end{tabular}




\section{Geographic Dispersion}

The geographic dispersion of the Internet is assessed through the number of Points of Presence (POPs) located in a nation's first-tier political subdivisions. In Uganda, there is at least one POP in the headquarters of each first-tier political subdivision or districts. According to the Uganda Communications Commission, there are a total 52 POPs with 24 others under development in the country (UCC, 2009b). While these POPs are relatively dispersed around the country, many of the 25 ISPs are located in Kampala with some having regional offices outside the first-tier political centers. Based on these numbers, we rate Uganda's geographic dispersion as moderately dispersed and therefore at Level 2 on the GDI geographic dispersion dimension (Table 4).

\begin{tabular}{|l|l|}
\hline \multicolumn{2}{|c|}{ Table 4. Geographic Dispersion of the Internet in Uganda } \\
\hline Level 0 & $\begin{array}{l}\text { Non-existent: The Internet does not exist in a viable from this country. No } \\
\text { computers with International IP connections are located within the country. } \\
\text { A country may be using UUCP connections for e-mail and USENET. }\end{array}$ \\
\hline Level 1 & $\begin{array}{l}\text { Single location: Internet points-of-presence are confined to one major } \\
\text { population center. }\end{array}$ \\
\hline Level 2 & $\begin{array}{l}\text { Moderately dispersed: Internet points-of-presence are located in multiple } \\
\text { first-tier political subdivisions of the country. }\end{array}$ \\
\hline Level 3 & $\begin{array}{l}\text { Highly Dispersed: Internet points-of-presence are located in at least 50\% } \\
\text { of the first-tier political subdivisions of the country. }\end{array}$ \\
\hline Level 4 & $\begin{array}{l}\text { Nationwide: Internet points-of-presence are located in essentially all first- } \\
\text { tier political subdivisions of the country. Rural access is publicly and } \\
\text { commonly available. }\end{array}$ \\
\hline
\end{tabular}

\section{Sectoral Absorption}

The sectoral absorption dimension measures the degree of utilization of the Internet by key sectors in a country. These include the academic, health, business, and public (government) sectors. Utilization is in turn assessed through the level of connectivity and server ownership in the sectors. Available data suggest that in areas such as health and government, connectivity is moderate and extremely limited. Several organizations operate their own servers. Tables 5 and 6 show the level of absorption in the different sectors as of 2003 (Sectoral data for recent years are not available.) 


\begin{tabular}{|l|l|l|l|}
\hline \multicolumn{4}{|c|}{ Table 5. Internet Usage by Different Sectors } \\
\hline \multicolumn{1}{|c|}{ Sector } & \multicolumn{1}{|c|}{$\begin{array}{c}\text { Minimal } \\
\text { (1 point) }\end{array}$} & \multicolumn{1}{c|}{$\begin{array}{c}\text { Medium } \\
\text { (2 points) }\end{array}$} & $\begin{array}{c}\text { Great Majority } \\
\text { (3 points) }\end{array}$ \\
\hline $\begin{array}{l}\text { Academic (primary } \\
\text { secondary and sec- } \\
\text { ondary schools, uni- } \\
\text { versities) }\end{array}$ & $\begin{array}{l}>0 \%-10 \% \text { leased line } \\
\text { Internet connectivity }\end{array}$ & $\begin{array}{l}10 \%-90 \% \text { leased line } \\
\text { Internet connectivity }\end{array}$ & $\begin{array}{l}90 \% \text { leased line In- } \\
\text { ternet connectivity }\end{array}$ \\
\hline Commercial & $\begin{array}{l}>0 \%-10 \% \text { Internet } \\
\text { Servers }\end{array}$ & $\begin{array}{l}10 \%-90 \% \text { Internet } \\
\text { Servers }\end{array}$ & $90 \%$ Internet Servers \\
\hline $\begin{array}{l}\text { Health (hospitals and } \\
\text { clinics) }\end{array}$ & $\begin{array}{l}\text { Internet connectivity } \\
\text { Intern leased line }\end{array}$ & $\begin{array}{l}10 \%-90 \% \text { leased line } \\
\text { Internet connectivity }\end{array}$ & $\begin{array}{l}90 \% \text { leased line In- } \\
\text { ternet connectivity }\end{array}$ \\
\hline $\begin{array}{l}\text { Public (top- and } \\
\text { second-tier govern- } \\
\text { ment entities) }\end{array}$ & $\begin{array}{l}>0 \%-10 \% \text { Internet } \\
\text { servers }\end{array}$ & $\begin{array}{l}10 \%-90 \% \text { Internet } \\
\text { servers }\end{array}$ & $90 \%$ Internet servers \\
& & & \\
\hline
\end{tabular}

\begin{tabular}{|l|l|}
\hline \multicolumn{2}{|c|}{ Table 6. Sectoral Absorption of the Internet in Uganda } \\
\hline Sectoral Point Total & Absorption Dimension Rating \\
\hline 0 & Level 0: Non-existent \\
\hline $1-3$ & Level 1: Rare \\
\hline $4-6$ & Level 2: Moderate \\
\hline $7-9$ & Level 3: Common \\
\hline $10-12$ & Level 4: Widely Used \\
\hline
\end{tabular}

\section{Connected classrooms}

Initial efforts to integrate ICTs in education in Uganda were spearheaded in 1997 by the Uganda VSAT Rural Connectivity Project. This was an initiative of the World Bank Institute ICT for Education Program (formerly World Links for Development - World). The program in Uganda was the first of such initiatives, which later expanded to 27 in different parts of the developing world. The project, which actually started in 2002 (after years of consultations and feasibility studies), was aimed at piloting "new concepts in technology and pedagogy to integrate Information and Communication Technology (ICT) in education in developing countries" (Hawkins, van der Ven, \& Rubira, 2004, p. 5). The project was also intended to "reverse the typical North-toSouth flow of Internet-based information and to promote the acquisition and dissemination of locally produced content" from Uganda (Hawkins et al., 2004). It began with the provision of VSAT-enabled high-speed Internet connectivity and computers to 14 high schools in various parts of the country and one teachers' college. One of the schools was the 2000-student Mbale Senior Secondary School in eastern Uganda. There, the project provided opportunities for teachers' professional development, improvement of efficiency in resource management and student data.

SchoolNet Uganda grew out of the World Links partnership. It was aimed at helping to "plan, support and build capacity for the use of ICTs in education in Uganda as a strategy of improving learning achievements and teacher performance in the classroom" (SchoolNet Uganda, 2008). The organization specifically targeted ICTs as major institutionalized tools in the "classroom instruction process, knowledge acquisition and sharing" (SchoolNet Uganda, 2008). Its current 
projects include the Uganda Digital Education Resource Bank (an "online repository of learning objects relevant to the Uganda educational system") and a program to inspire girls to study science through ICTs. While SchoolNet has been relatively successful in achieving its goals of integrating ICTs in education, its projects are mostly targeted at secondary schools.

Besides SchoolNet, computer education has since become an integral aspect of the traditional national program for secondary schools under the auspices of the ministry of education. Computer-based learning practices and online resources for secondary schools have also expanded beyond the initial 15 institutions in the World Links pilot project. The country's ICT for Development National Policy includes a plan to integrate "ICT into all educational curricula" (Uganda Ministry of Works, Housing and Communication, 2003). We however found no evidence of a specific policy on the integration of ICTs and Internet connectivity provision at the primary level, which has approximately 7.6 million students and 85,000 teachers in the country (MyUganda, 2008; Ssekandi \& Chen, 2005). At the tertiary level, Makerere University leads the pack of at least 17 universities in the country with its significant ICT usage (as noted earlier). Other universities have developed ICTs in varying degrees of intensity. Most have the basic Internet access for top officials and in the libraries.

\section{Networked health}

The health sector has often been close behind academic institutions in adopting ICTs in many developing countries. In Uganda, this sector was also an early entrant as initial assumptions about ICTs as tools for development frequently focused on their utilities in the education and health sectors. Uganda's Ministry of Health demonstrated understanding of the benefits of ICTs in the health delivery processes. One of the main goals of the ministry was to generate awareness and sense of urgency on the need for computer literacy and ICT usage in the healthcare delivery sector. Over the years, the ministry acquired ICT products such as computers, many of which were installed at the headquarters and used mostly for administrative functions.

\section{ICTs in the public sector}

The public sector uses various ICTs in one form or the other especially as different policies emphasize the need for government ministries to utilize more ICTs in their routine tasks to achieve the country's millennium development goals, such as reducing poverty, disease, hunger, and illiteracy (Tashobya and Ogwal, 2004). The technologies are expected to stimulate many development processes and could, if prioritized by individual government ministries, help to eradicate poverty, improve healthcare, and promote education. For instance, the Ugandan National ICT Policy Framework includes e-commerce and ICT-based services in "the eight priority areas to increase the country's exports, particularly through the Smart Strategic Partnership program between government, private investors and development partners" (The Republic of Uganda, 2003). ICT utilization in the public sector has increased especially with key government officials strongly advocating their potential to help Uganda to leapfrog several stages of development. The National ICT Policy Framework equally identifies ICTs as one of those priority areas in the country's development process.

\section{Connectivity Infrastructure}

Connectivity infrastructure is a measure based on international and intra-national backbone bandwidth, exchange points, and last-mile access methods. Uganda was one of the first countries in East Africa to attain complete Internet connection (UNECA, 2009). It is now the seventh on the list of top 10 Internet countries in Africa (Internet World Stats, 2009). In Uganda, the first provider of Internet services was InfoMail which established a VSAT-based service via MSN in the USA. The second ISP was STARCOM, a Uganda licensed company sponsored by a multi-million 
dollar investment from Telenor (the Norwegian national telecom carrier), as well as by US and Ugandan investors. InfoMail and Starcom later merged and formed a new ISP called Infocom, now considered one of the three major ISPs along with MTN and Ugandan Telecommunications Limited (UTL).

There are currently 25 licensed ISPs in the country providing Internet connectivity through various access methods: dial-up, leased line, broadband, VSAT, GPRS, and Hot Spots. These access methods have obviously expanded beyond the basic binaries of modem or leased line as originally conceptualized in the GDI framework. However, the band of Internet connectivity may lie between the levels of Expanded and Broad. This shows that the GDI framework may not quite capture the advancement of technologies and other developments in the Internet sector. Also the ubiquity of Internet cafés (numbering more than 300) in Uganda diffuses Internet usage faster and more broadly than can be measured by a narrow conceptualization of Internet connectivity as either through modem or leased line.

It must be noted that while a higher percentage of Internet activity occurs in the urban centers the technology has expanded to the rural areas as well through UCC's Rural Communications Development Fund (RCDF). There is at least one cyber café in each district in the country as well as POPs in 54 regional centers. This expansion has been facilitated by the deployment of technologies such as Wi-Fi and Wimax which provide easier and faster access to the Internet. WiMax can carry more than 70Mbit/s connection over 50 kilometers making it suitable for broadband connections in infrastructure-poor areas. The Battery Operated Systems for Community Outreach (BOSCO), an Indiana, US-based nongovernmental organization, has extended Internet connectivity to the war-torn northern region through solar power. A discussion of this initiative follows below in the section on the Internet and conflict in Northern Uganda.

\section{Domestic Backbone}

Uganda has built an "internal backbone fiber cable ahead of the other East African countries so as to reduce its internal Internet weaknesses" (Kazooba, 2008). The first phase of the \$30 million Ugandan National Data Backbone project was completed in April, 2008. It was birthed by a partnership of the Ugandan Ministry of Information and Communication Technology with Huawei, a Chinese company. "It comprises two technologies (fibre-optics and cable) and will be laid mainly around Kampala and along the transmission routes in the eastern, western and northern parts of the country" (MyBroadband, 2008).

Prior to the construction of the national data backbone, some ISPs had starting laying their own fiber networks. As well, microwaves for smaller backbone links into the more rural areas feeding off the main fiber optic routes have been set up. The private network will see MTN complete a fiber link to the Kenyan border to link up with the Telkom Kenya fiber that eventually runs from Malaba to Nairobi to Mombasa to form a section of the East African Backhaul System (EABS) project, a joint venture among operators from Tanzania, Burundi, Rwanda, Uganda, and Kenya (MyBroadband, 2008). MTN and UTL both have fiber optic rings in Kampala. The national service providers have a range of products with varying bandwidths, e.g., UTL has the following products with corresponding bandwidth:

$$
\begin{array}{ll}
\text { ADSL } & 256 \mathrm{kbps}-6 \mathrm{Mbps} \\
\text { HDSL } & \text { Fixed rate of } 2 \mathrm{Mbps} \\
\text { ISDN } & 64 \mathrm{Kbps}-128 \mathrm{Kbps}
\end{array}
$$

International connectivity is offered primarily through a satellite earth station at Mpoma, near Kampala. A majority of Uganda's Internet passage is routed outside the country (Minges, Brown, \& Kelly, 2001). However, there was noticeable growth in international bandwidth in 
2007. According to the 2007 Market Review issued by the UCC, total bandwidth increased to 344 mbps (257.5 mbps downlink and 86.9 mbps uplink.)

\section{Internet exchanges}

An Internet exchange point (IX or IXP) is a tangible infrastructure that enables various ISPs to exchange Internet passage between their networks by means of joint peering agreements, which allow passages to be exchanged without expenses (Ugandan Internet Exchange Point [UiXIP], 2009). An IXP enables networks to interconnect directly via the exchange rather than through other networks. In the absence of an IXP, connections between ISPs in a country are routed through another country to a global connection thus increasing transaction costs and time (Wolcott et al., 2001). According to Masambu (2001), an IXP facilitates transfer of local information/messages between the ISPs sparing the capacity for international bandwidth links for the transfer of information to and from countries outside Uganda. This leads to a reduction in costs of 'intra-country' Internet traffic. An IXP also reduces congestion on international traffic routes resulting in better utilization of the international Internet capacity and improved quality of service. The Ugandan Internet exchange point (UiXP), an initiative of stakeholders of Uganda's local Internet community who share a common goal for a robust, fast and stable local Internet backbone, is now running following several months of intense debates, and licensing from the Ugandan Communications Commission (Ugandan Internet Exchange Point [UiXIP], 2009).

\section{Access methods}

As noted earlier, there are several access routes to the Internet in Uganda. These include dial-up, leased line, broadband, VSAT, GPRS, and Hot Spots. In recent years though, there has been a significant increase in the "deployment of wireless access infrastructure based on WiFi/WiMax hot spots" (UCC, 2007) as well as Internet connectivity through mobile phones. One notes though that the location of hot spots is not evenly spread because, of the estimated 30 hotspots, about 95\% are located in the Kampala area. Most Internet access is therefore still through dial-up given the relatively low cost. Demand for other access methods is growing, however, as advances in the various technologies drive down costs.

A 2005 study conducted by the UCC indicated that a majority of the people use dial-up service $(43 \%)$, with leased lines on copper and fiber optic cables and wireless service taking $35 \%$ and $22 \%$ respectively. While the results show a steady and remarkable improvement in the usage of leased lines and wireless technologies, few Ugandans can afford the cost of related ICT equipment and services. Most Internet users therefore take advantage of community access points. The establishment of 54 POPs by the RCDF is expected to further expand such access. "Under the same project 54 ICT training centers and 50 Internet cafes have been set up countrywide through competitive bidding process for government subsidies of private sector firms" (UCC, 2006a). In addition, a pilot telecenter in Nakaseke, a rural area in central Uganda, was funded by international donors who expected that it would lead to similar community-based centers in the rural Uganda.

A new and fast growing access to the Internet in Uganda is through mobile telephones. According to the UCC, "Internet usage in Uganda is gradually shifting from traditional fixed access to mobile wireless access" (Wireless Federation, 2008). This is a "direct result of operators investing millions of dollars into network upgrades" (Wireless Federation, 2008). Infocom, one of the ISPs in Uganda, started offering Internet service through the cell phone in 2006. It was not until a year later when MTN, a cell phone service provider, launched a mobile office with full Internet service that mobile Internet became common among the elites in Kampala. Infocom later expanded its mobile Internet service through "WiMax and the introduction of a new broadband offering called SpeedMax" (Wireless Federation, 2008.). The outcome of these developments is that in the first 
quarter of 2008, about 175,568 users in Uganda accessed the Internet through smart phones and hot spots ( Wireless Federation, 2008.) This is expected to increase as more Ugandans use the cell phone. In 2008, there were 27cell phone subscribers for every 100 inhabitants in Uganda. The increase in mobile Internet may partly explain the rise of Uganda to the seventh spot on the ranking table of most Internet-penetrated countries in Africa in 2008 (ITU, 2009a). Nevertheless, the high cost of access to the Internet is likely to limit the number of users who depend on this method for regular access.

\section{Organizational Infrastructure}

The organizational infrastructure is a measure based on the state of the ISP industry and market conditions (Press, 1997; Press et al, 1998). The criteria include free admission to the ISP market, paid licensing of ISPs with a provision of up to two percent of annual revenue to the communications development fund (Minges et al., 2001). Recent statistics from UCC indicate that there are 25 registered ISPs with MTN and UTL holding a large percentage of the market. There have been developments in the ISP business with five companies collaborating to purchase bandwidth. This is expected to cut down the cost of bandwidth. Accordingly, each ISP in Uganda could buy up to 2-3 Meg of bandwidth for small ISPs while the big ones may procure 5-6 Meg per month. Each megabyte costs $\$ 5,000-\$ 6,000$ to be landed in Uganda (Nakkazi, 2006). Purchasing shared bandwidth has a number of advantages, one of which is a $25 \%$-purchase discount on 50 megabytes. As illustrated in Table 7, these numbers place Uganda at Level 3 (Competitive) on the GDI framework dimension of organizational infrastructure.

\begin{tabular}{|c|l|}
\hline \multicolumn{2}{|c|}{ Table 7. Organizational Infrastructure of the Internet in Uganda } \\
\hline Level 0 & None: The Internet is not present in this country. \\
\hline Level 1 & $\begin{array}{l}\text { Single: A single ISP has a monopoly in the Internet service provision mar- } \\
\text { ket. The ISP is generally owned or significantly controlled by the govern- } \\
\text { ment. }\end{array}$ \\
\hline Level 2 & $\begin{array}{l}\text { Controlled: There are only a few ISPs and the market is closely controlled } \\
\text { through high barriers to entry. All ISPs connect to the international Inter- } \\
\text { net through a monopoly telecommunications service provider. The provi- } \\
\text { sion of domestic infrastructure is also a monopoly. }\end{array}$ \\
\hline Level 3 & $\begin{array}{l}\text { Competitive: The Internet is competitive. There are many ISPs and low } \\
\text { barriers to market to market entry. The provision of international links is a } \\
\text { monopoly, but the provision of domestic infrastructure is open to competi- } \\
\text { tion, or visa versa. }\end{array}$ \\
\hline $\begin{array}{l}\text { Robust: There is a rich service provision infrastructure. There are many } \\
\text { ISPs and low barriers to market entry. International links and domestic } \\
\text { infrastructure are open to competition. There are collaborative organiza- } \\
\text { tions and arrangements such as public exchanges, industry associations, } \\
\text { and emergency response teams. }\end{array}$ \\
\hline
\end{tabular}

\section{Sophistication of Use}

Sophistication of use is a measure that distinguishes usage in terms of conventional, highly sophisticated or driving innovation (Press et al., 1998). The most common Internet activity in Uganda is e-mail and, though the sophistication level is gradually increasing given the number of initiatives implemented by businesses in recent years, we rate this dimension on Level 3: transforming (Table 8). For instance, some banks now allow online transactions by their corporate and high net worth clients, and travel agencies and hotels allow their customers to make online reser- 
vations. At the individual level, many users are spending a lot of time "browsing" (a general term for all Internet activities other than e-mailing) and downloading music and software (Mwesige, 2004; Tushabe \& Baryamureeba, 2005).

Individuals and organizations also develop personal or business web sites, with some specializing in e-commerce. In cyber cafés, e-mailing remains the common Internet activity but some establishments have expanded their offerings with many including computer training classes for customers who wish to log onto the Internet by themselves rather than use center staff. When customers go online on their own, they typically spend more time and therefore the cyber café gains both from the training fees and usage fees. The customers are not complaining either because their time on the Internet is also business. A report quotes a metal worker who uses the telecenter in Nakaseke (referred to earlier) to download designs for his metal fabrication business. This allows him to manufacture sophisticated window frames and gates much to the delight of his discerning clientele in the local building industry ("Pilot Telecenter in Uganda is Successful," 2006).

Another customer at the same telecenter is a secondary school teacher who goes online to search for scholarship opportunities for his students. He reports success in connecting some of his students with international donors willing to pay their tuition fees ("Pilot Telecenter in Uganda is Successful," 2006). This particular telecenter was itself sponsored by the Uganda Rural Communications Development Fund in collaboration with UNESCO and the Canadian International Development Research Center. It was a pilot project aimed at testing to "see whether the lives of people in rural areas would change" as a result of the Internet (("Pilot Telecenter in Uganda is Successful," 2006). Similar centers were planned for other rural areas in the country.

\begin{tabular}{|c|l|}
\hline \multicolumn{2}{|l|}{ Table 8. Sophistication of Use of the Internet in Uganda } \\
\hline Level 0 & $\begin{array}{l}\text { None: The Internet is not used, except by a very small fraction of the popu- } \\
\text { lation that logs into foreign services }\end{array}$ \\
\hline Level 1 & $\begin{array}{l}\text { Minimal: The user community struggles to employ the Internet in conven- } \\
\text { tional, mainstream applications. }\end{array}$ \\
\hline Level 2 & $\begin{array}{l}\text { Conventional: The user community changes established practices some- } \\
\text { what in response to or in order to accommodate the technology, but few } \\
\text { established processes are changed dramatically. The Internet is used as a } \\
\text { substitute or straightforward enhancement for an existing process (e.g. e- } \\
\text { mail vs. post). This is the first level at which we can say that the Internet } \\
\text { has taken hold in a country. }\end{array}$ \\
\hline Level 3 & $\begin{array}{l}\text { Transforming: The use of the Internet by certain segments of users results } \\
\text { in new applications, or significant changes in existing processes and prac- } \\
\text { tices, although these innovations may not necessarily stretch the bounda- } \\
\text { ries of the technology's capabilities. }\end{array}$ \\
\hline Level 4 & $\begin{array}{l}\text { Innovating: Segments of the user community are discriminating and } \\
\text { highly demanding. These segments are regularly applying, or seeking to } \\
\text { apply, the Internet in innovative ways that push the capabilities of the tech- } \\
\text { nology. They play a significant role in driving the state-of-the-art and have } \\
\text { a mutually beneficial and synergistic relationship with developers. }\end{array}$ \\
\hline
\end{tabular}




\section{Communication and Conflicts}

So far we have described the development of the Internet in Uganda beginning with early efforts at connectivity. We have also presented an overview of the policy framework and the factors that have facilitated or hindered the greater diffusion for the Internet, the level of which we have evaluated against the parameters of the GDI framework. Rarely are technologies developed or designed without a specific purpose. This is more so with information and communication technologies (ICTs) and related networks, systems and applications. With telecommunication networks, particularly, the expectations were beyond the basic utility of enhancing communication and access to information. Much more was expected of these technologies and the expectations underpin the discourse on ICTs for development that has dominated development theory and practice since the 1990s. Specifically, it was argued that ICTs had the potential to help African countries to overcome many of the constraints that hinder development (Akpan-Obong, 2009).

While Uganda suffers from the same problems of underdevelopment as other African countries, its case has been exacerbated by persistent internal conflicts in the northern region. Officially, the war between the Lord's Resistance Army (LRA) and the Ugandan government of Yoweri Museveni, which started in the 1980s, ended with the signing of the Final Peace Agreement in 2006. The Ugandan national army has since taken control of the region. Unofficially however, the war rages on as the LRA leader, Mr. Joseph Kony, refuses to surrender or honor the terms of the 2006 agreement. The Northern Region was the base of the LRA and therefore the frontline of the 23year-old war. There are many causalities of this war including the displacement of millions of Acholis (the ethnic group in the northern region) from their homes with many of them spending years in Internally Displaced Persons Camps.

It is into these camps that many nongovernmental organizations such as BOSCO and Inveneo have taken the Internet as a technology to foster peace and reconciliation but mostly to provide a voice to the war victims to tell their stories to the world. In the next section, we explore the role of the Internet in the post-conflict efforts to reconcile and rehabilitate the casualties of the civil war in northern Uganda. We begin with a discussion of the role of ICT-mediated communication and dialogue in conflict. This will be followed by a study of the work of BOSCO and Inveneo to provide Internet access as an instrument of post-war reconciliation and reconstruction to the Acholis in war-torn Northern Uganda.

\section{ICT-Mediated Communication and Conflict}

Communication and dialogue have always been identified as important precursors of diplomacy. This in turn advances peaceful resolution of conflicts particularly at the international arena. In this sense, therefore, there is nothing novel about the deployment of ICTs as tools for conflict resolution, except that they potentially and exponentially enhance the process. Indeed, research shows that since the end of the Cold War "half of all conflicts have been ended through communication and peace talks between conflict parties (Wehrenfennig, 2006, p. 1). While Wehrenfennig does not go as far as crediting the Internet with these developments, it is undeniable that the end of the Cold War in 1992 was quickly followed by the explosion of the Internet in the public domain in 1993. The technology certainly existed long before the 1980s (in fact, since 1969) but it was used mostly in the military and in research and academic institutions. From the late 1980s and much of the $1990 \mathrm{~s}$, many countries began to actively expand Internet access to the general public through policies and legislations. In the United States, there was the High Performance Computing and Communication Act of 1991 (also referred to as the Gore Bill, after then-Senator $\mathrm{Al}$ Gore, its sponsor). The bill later led to the establishment of the National Information Infrastructure. 
Many scholars, such as Held, McGrew, Goldblatt, and Perraton (1999), have argued that advancements in ICTs have created more efficient and faster ways of communication across cultural and geographical borders. The technologies therefore enhance networking and connectedness in ways that potentially foster understanding, friendship, and peace through various processes. In the first place, citizens have the opportunity to communicate more directly with each other and interpret information for themselves without interference from politically invested intermediaries. In addition, civil society organizations such as Amnesty International and Human Rights Watch can receive information about brewing conflicts and quickly disseminate peace-building messages to targeted populations more immediately and directly.

Online forums and newsgroups provide opportunities for parties on different sides of a conflict to have open and honest discussions without exposing themselves to physical danger. In the case of Uganda, a quick Internet search shows as many as 124 newsgroups in the Yahoo! Groups Directory alone. These online groups are organized around various interest areas with Uganda being the common rallying point. Some of the groups are based on professional, religious, and ethnic groups. There are also umbrella groups, such as Ugandans Abroad, which cut across primordial interests. One of these is "Area256" with 24 members. Its objectives are to "talk, contribute, discuss about anything Ugandan or related to Uganda from health, education, politics, religion, relationships, business, innovations ..." (Yahoo! Groups Directory, 2009).

Another general interest group is UNAANET which currently has 368 members. It is a "discussion group for members of the Ugandan North American Association and other Ugandans in the Diaspora" (Yahoo! Groups Directory, 2009). Four narrow-interest groups specific to our discussion on the war in Northern Uganda are:

- NUWG (67 members) - a working group on northern Uganda for DC-based advocates;

- GuluWalk-Kampala (10 members) - a "team of Ugandans resident in Kampala, standing in solidarity and supporting the cause for an end to the 'Night Commuter Crisis' in Northern Uganda;"

- Ugandan_women_peacebuilders (5 members) -focused on increasing the voices of women and bringing peace to Northern Uganda;

- SavetheNightWalkers (5 members) - committed to supporting the relief and saving efforts of the children and toddlers who are being murdered, abducted, abused and recruited to fight in Joseph Kony's rebel army. Thousands of messages are exchanged daily in these groups to promote their general interest or specific causes.

The Internet thus provides a forum for Ugandans to dialogue with each other on the issues that affect them as a people belonging to one geographical entity. In such forums, ethnic differences are ostensibly submerged in the collective national group identity. If communication and dialogue are precursors to conflict resolution and peacebuilding, it is therefore possible that the greater the access to the Internet that Ugandans - both at home and in the Diaspora - have the greater the chances to communicate and thus peacefully resolve internal conflicts, or at least create understanding of each other's positions.

Finally, online social networks such as Facebook and MySpace foster personal relationships and friendships among people from different parts of a country. For these reasons some nongovernmental organizations operating in the war-torn Northern Uganda, stronghold of the LRA, have assisted many Ugandans from the region to use Internet blogs, YouTube, and social networks to tell their personal stories of the war. Clearly, positive communication can promote understanding. This is more so when it is enhanced and accelerated by ICTs such as the Internet. 
We quickly acknowledge the fact that open communication is a two-edged sword. It can foster understanding as well as increase the conflict. For example, terrorist groups can take advantage of better communication systems to organize for the purposes of creating conflicts and violence (Held et al., 1999). The attacks on the United States on September 11, 2001 benefited from well coordinated communication among the perpetrators. As Held and colleagues argue, "Growing interconnectedness may be a source of intense conflict (rather than cooperation) as well as a product of shared fears and deeply held animosities" (p. 28).

The technologies can serve as propaganda tools to foment hatred and dissension. Rebel and terrorist groups have been known to create websites through which they disseminate information and pass on secret messages to its members. Also radio talk shows have been used to cause as much harm as they can create goodwill among different groups of people. "They can intensify the conflict under discussion, and rather than inform listeners, make them angry or fearful, or with the sense that the conflict will go on forever. They can make destructive conflict seem the inevitable response to all disagreements and destabilize communities" (Howard \& Rolt, 2006). This was precisely what occurred in Rwanda in 1994 when the Hutus used the radio heavily to whip up hatred against the Tutsis and Hutu moderates. The outcome was the massacre of 800,000 Rwandans in nine months in 1994 as neighbors, friends, and families turned against each other (Olojede, 2004).

\section{Internet and the war in Northern Uganda}

While the Rwandan war was one of the most brutal conflicts in Africa, it lasted less than a year. Across its northern border, a different war has been brewing for more than 23 years now in the Northern Ugandan districts of Gulu, Pader, Kitgum, and Amuru. This is the stronghold of the quasi religious war of the Lord's Resistance Army (LRA), led by a Gulu native, Joseph Kony. The LRA has been fighting against the Uganda government since the 1980s. It seeks to overthrow the national government and to replace it with a government that derives its principles of law and governance from the Ten Commandments. While the LRA claims to be fighting a moral war, its methods have been decidedly immoral and criminal. Operating out of southern Sudan (which created hostilities between Sudanese and Ugandan governments), the LRA has been notorious for committing "numerous abuses and atrocities" such as "abduction, rape, maiming, and killing of civilians, including children" (Global Security, 2009). It was particularly infamous for recruiting young children as soldiers, sex slaves, and concubines. The activities of the LRA extended beyond the Ugandan borders into Sudan, Rwanda, and the Democratic Republic of Congo, and are implicated in many conflicts in East and Central Africa. While a peace agreement was signed between the LRA and the Ugandan government in 2006, the rebels have refused to surrender or disarm and continue to terrorize many countries in the central and eastern African region.

Prior to the 2006 Final Peace Agreement, the LRA concentrated its attacks mostly in the four Acholi districts. About two million Acholi people were consequently forced off their land. After the national army took control of these areas, the people were placed in camps for Internally Displaced Persons (IDP) where they have lived for many years. Consequently, "generations (of Acholi people) have not known a home in the country of their birth, nor its proud history" (Drakard, 2009). Many international organizations and governments have been involved in the drawnout process of peacemaking and rehabilitation in the region through traditional approaches.

The United States Government, through its Agency for International Development (USAID), has been involved in the peace process by funding programs and projects aimed at returning normalcy to the area. It has also invited internally displaced persons to return to their communities while encouraging members of the LRA to disarm voluntarily and return home. To achieve these goals, schools, hospitals, and community centers have been built or repaired and technological expertise provided via computers, engineering software for engineering staff in Gulu and Amuru (Embassy 
of the United States, 2009). The USAID Office of Transition Initiatives went as far as facilitating traditional cleansing of the land. "An example of this occurred as returnees found bodies of those killed during the conflict on their land. Traditional leaders must cleanse the land and re-bury the bones to allow returnees to be free from the trauma of the conflict that they often describe as the ghosts of those killed" (Embassy of the United States, 2009).

Communication through the media has been a major tool in the recovery and resettling process in Northern Uganda since the LRA moved its heavy fighting away from the area. By far however, the most effective of these media has been the radio because of its geographical reach and accessibility. Through this medium, information is transmitted to displaced persons within and outside the northern region about the condition of life at home as well as encouraging them to return. By April 2009, about 538,000 displaced persons had returned to their villages in the four Acholi districts. "On the surface life is getting back to normal in northern Uganda, thanks to the work of many NGOs and the resilience of the people themselves" (Drakard, 2009).

Beyond the radio, Internet connectivity has become a pivotal tool in the peace and reconciliation process in Northern Uganda through the activities of an Indiana, United States-based nongovernmental organization, the Battery Operated Systems for Community Outreach (BOSCO) created in 2007. The story of BOSCO's work among the Acholi people began with a chance encounter in Indiana between a Catholic priest and a lay church minister. The priest, Father Robert Binta, was from Uganda and the lay Catholic minister was Gus Zuehlke, a man from St. Bavo Catholic Parish in Mishawaka in Indiana. That meeting resulted in a friendship which later led to the establishment of BOSCO in 2007 specifically to give voice to victims of the war in Northern Uganda.

BOSCO utilizes ICTs, particularly the Internet, to help people in IDP camps in Northern Uganda to connect with each other and, most importantly, to tell their stories to the outside world. The organization has created computer and communication hubs powered by solar energy in centers that serve as sources of education, emergency communication link and "a means for these oppressed people to have their voice heard, to get their story out to a world which has not, until now, heard their cry" (BOSCO-Uganda, 2009). According to information on the organization's websites, its networks provide "flexibility and expandability, and ... extremely low cost due to the use of $12 \mathrm{~V}$ DC equipment, which vastly lowers the amount of power usage, and therefore the amount of solar power needed." As of 2008, the organization had "installed wireless networks in seven IDP camps around the Gulu district. (Also) health centers, dioceses and schools have been equipped with Internet connections and phones facilitating free communication worldwide" (Anstis, 2008). BOSCO's technology works "virtually anywhere the sun shines" and the networks will be extended to all the 20 current displacement camps in the region and ultimately connected the surrounding villages (Anstis, 2008). The goal was to provide coverage to one-third of Uganda's land area of about 28,000 square kilometers that make up the Northern Uganda region (Anstis, 2008; BOSCO-Uganda, 2009).

Through such Internet connectivity, disarmed soldiers and victims of the war have an opportunity to tell their stories to the outside world through various avenues on the Internet but especially on BOSCO's wiki pages, blogs, newsgroups and social networks. One of these people is a man called Jokondino who keeps a journal on one of BOSCO's Wiki spaces. From some of his stories, one gets the impression that Jokondino is a teacher who lives in an IDP in Gulu, one of the four districts in Northern Uganda. As of November 22, 2009, he had 20 entries in his journal with wide-ranging topics. Some entries are photographs and poems. He also uses the entries to indicate the needs of the people. For instance, in "Lacor Primary School," he posts information about a school including photographs of the school building and students in the classrooms. He ends the entry with information that the school "is in need of rechargeable batteries for the camera and battery charger." 
In the discussion part of Jokondino's Wiki page, a teacher from a school in the US responded with a tentative promise to send school supplies to the school as well as work on collaborative projects between Jokondino's students and hers. Jokondino therefore uses his journal to accomplish much more than tell stories of war. But when he does, the impact is visceral as he gives voice to unspoken fears and dreams unutterable during the war. An example is a two-part poem titled, "Weep Not, Mother," which he dedicates "to all the people in Northern Uganda who have undergone a bitter civil strife." The poem begins with this verse:

Don't cry mother please don't weep;

When the beasts storm your house.

Keep quiet and don't utter a word,

Like a sheep being led to the abattoir,

Don't say anything it's useless. (Jokondino, n.d.)

BOSCO's programs also spin off other related projects. For instance, using a wireless Internet connection provided by the organization, the Pabo diocese applied for an international grant to fund solar panels for its health center. The diocese got the grant and the now has "an Internet phone (used to make free calls to) anywhere in the world, and students at Pabo secondary schools are sharing stories of abduction and war on personal blogs" on the Internet (Anstis, 2008). Another organization, Inveneo, also seized the opportunity provided by BOSCO to partner with it to enhance its capacity to provide access to computers, Internet, and voice-over-Internet-Protocol (VoIP) telephony for about 10,000 refugees in IDP camps in Northern Uganda (Soul Beat Africa, 2008).

Inveneo also provides solar-powered wireless Internet network in the camps and in organizations that serve the IDPs and other Acholis fleeing from the LRA. Specifically, the Inveneo wireless network provides Internet connectivity from Gulu to seven IDP camps about 70 kilometers away. "The system is designed to be operable on 12 volts with a range of power options, and is resistant to heat, humidity, and dust, so that it can operate in environments where computing has traditionally not been found" (Soul Beat Africa, 2008). Similar to BOSCO's, Inveneo's goal is to give internally displaced persons, especially the children, a voice through technologies that connect them to the world outside the refugee camps so that they can become their own advocates (Soul Beat Africa, 2008). The organization has 20 projects in Uganda, Rwanda, Ghana, Mali, Guinea Bissau, and Burkina Faso.

While Internet connectivity may not have the same level of immediacy and direct impact as the radio on conflicts, it is evident that the technology can make a difference in the lives of war victims in Northern Uganda, if not on the war directly. In the first instance, the people, particularly children, are able to tell their stories in their own words and therefore be their own advocates. Secondly, people outside the region within Uganda and around the world can receive information about the atrocities committed among the Acholi people of Uganda. Already this information has yielded positive results for the people beginning with the BOSCO project itself. It was a chance encounter with a native of Acholi that caused the founder of the organization, Gus Zuehlke, to get involved, first by visiting the area to access the needs of the people, and then by getting his church members in Indiana and other people to provide funds and begin the process that led to Internet connectivity and related technology in Northern Uganda. Through the Internet, a secondary school teacher has been able to improve the lives of his students by connecting them with overseas donors who offer the students tuition scholarships that allow them to complete their education. An educated Acholi youth has better life chances and is therefore less likely to volunteer for the LRA. The totality of these activities and others underscores the point that the Internet in Uganda and particularly in the northern region will have positive impact on the people. The greater the diffusion levels therefore, the more significant the impact. 


\section{Conclusion}

Uganda was one of the first countries in Africa to achieve full Internet connectivity. It moved relatively quickly from 125,000 users in 2003 to 2.5 million by the middle of 2009 . It ranks seventh on the list of African countries with the highest numbers of Internet users. The country fares well on the Global Diffusion of the Internet framework, though closer examination reveals less of the slow pace of Internet development in Uganda than the weakness of the framework itself to measure current levels of global Internet diffusion. Generally, the raw numbers on specific GDI dimensions are low but they rate very well on the GDI tables. A notable exception is with the Sophistication of Use dimension as reflected in Internet usage among Ugandans living in internally displaced persons camps in the Northern Region.

Both Ugandans and international organizations have utilized the Internet extensively in the reconciliation and reconstruction processes in war-torn Northern Uganda region. BOSCO and Inveneo, nongovernmental organizations, have used solar-powered batteries to provide full-service Internet connectivity to Internally Displaced Persons camps in the northern region with the main aim of giving voice to victims of the decades-long war of the Lord's Resistance Army. The organizations considered it important that the people should be able to tell their stories to the outside world in their own voices and thereby be their own advocates. The technology has also been utilized to enhance and coordinate the ongoing efforts of transition from war to peace in the region. This level of Internet usage, beyond basic e-mailing, is not the norm in the country however. For the most parts, as research shows, majority of Internet users especially in cybercafés are engaged in e-mail activities.

Uganda also rates well on the Pervasiveness dimension. Incidentally, this dimension highlights most evidently the weakness of the framework in usefully analyzing Internet dynamism. When the framework was conceptualized in the 1990s, ten-percent Internet penetration level (Level 4 in Table 3) was the epitome of pervasiveness. At 7.7\%, Uganda is just one level away. And yet other dimensions such as geographic dispersion and sectoral absorption indicate that the country is still on the starting block in the journey to the information society which it began in 1993 with its first Internet connectivity. The GDI is a pioneering tool in the measurement of what was a new phenomenon not that long ago. It seems however that its utility has been overtaken by the pace of growth in global Internet diffusion though as it has facilitated our analysis of the different dimensions of Internet penetration in Uganda. The framework would certainly be ineffective in assessing Internet diffusion in many countries outside Africa.

We conclude by arguing that with Uganda ranking seventh on the list of ten African countries with the most Internet users, the country is evidently heading in the right direction. Beyond the numbers, it is significant to note that Internet access is not an end by itself but a means to solving many of the problems that beset the country. And for Uganda, once known as the Pearl of Africa, the war in its northern region has been a particularly persistent problem. Enhanced communication through the Internet may ultimately usher in peaceful relationships among the people and therefore create the environment for Ugandans to focus on socioeconomic development efforts. Indeed, even the improvements in the communication infrastructure may be evidence of development by itself.

\section{References}

Akpan-Obong, P (2009). Information and communication technologies in Nigeria: Prospects and challenges for development. New York: Peter D. Lang Inc.

Akpan-Obong, P., \& Foster, W. (2007). Africa's telecommunications giant awakes. Computing \& Communications Africa, 3(2). 
Anstis, S. (2008). Internet access fuels development in war-torn Uganda. Retrieved on November 17, 2009 from http://www.towardfreedom.com/home/content/view/1381/1/

Bernstein, A., \& Goodman, S. E .(2005). Global diffusion of the Internet VI: The Internet in Togo. Communications of the Association for Information Systems (CAIS), 15(6), 371-392.

BOSCO-Uganda. (2009). Origins of BOSCO. Retrieved November 17, 2009 from http://www.boscouganda.org/index-1.html

Drakard, M. (2009). Are the days of Lord's Resistance Army numbered? Energy Publisher. Retrieved on November 19, 2009 from http://www.energypublisher.com/article.asp?id=22901

Embassy of the United States. (2009). Peace process: Humanitarian and economic recovery. Retrieved on November 17, 2009 from http://northernuganda.usvpp.gov/humanitarian.html

Foster, W. A., \& Goodman, S. E. (2000). The diffusion of the Internet in China. Center for International Security and Cooperation (CISAC), Stanford University.

Gita, S., \& Ikoja-Odong, J. R. (2003). The impact of cybercafés on information services in Uganda. First Monday, 8(4). Retrieved June 92008 from http://firstmonday.org/issues/issue8_4/gitta/index.html

Global Security, (2009). The Lord's Resistance Army (LRA). Retrieved on November 17, 2009 from http://www.globalsecurity.org/military/world/para/lra.htm

Hawkins, R., van der Ven, M., \& Rubira, J. (2004). An overview of the Uganda Rural Connectivity VSAT Project - Project history \& end of pilot examination of sustainability. Retrieved on December 28, 2009 from http://www.ruralwings-project.net/portal/shared/workpackages/background/worldlinks-ugandafinal-report.doc/download

Held, D., McGrew, A., Goldblatt, D., \& Perraton, J. (1999). Global transformations: Politics, economics, and culture. Palo Alto, CA: Stanford University Press.

Howard, R., \& Rolt, F. (2006). Radio talkshows for peacebuilding: A guide. Retrieved on November 17, 2009 from http://www.comminit.com/en/node/187414/38

Idi Amin. (2009). Retrieved on March 26, 2009 from http://www.moreorless.au.com/killers/amin.html

International Telecommunications Union. (2009a). ICT statistics database. Retrieved on November 17, 2009 from http://www.itu.int/ITU-D/icteye/Indicators/Indicators.aspx\#

International Telecommunications Union. (2009b). Measuring the information society: The ICT development index. Retrieved on September 21, 2009 from http://www.itu.int/ITU-

D/ict/publications/idi/2009/index.html

Internet World Stats. (2009). Uganda. Retrieved September 21, 2009 from http://www.internetworldstats.com/af/ug.htm

Jokodino. (n.d.). Weep not, Mother. [A poem dedicated to "all the people in Northern Uganda who have undergone a bitter civil strife.] Retrieved November 22, 2009 from http://www.boscouganda.wikispaces.net/POETRY

Kazooba, C. (2008). Uganda rejects EASSy solution. The East African, Feb. 25. Retrieved on June 30, 2008 from http://allafrica.com/stories/200802251854.html

Makerere University. (2008). Makerere University Information and Communication Technology: ICT policy master plan phase 2 (2005 - 2009) (ICT services and systems; management, control and maintenance; master plan). Retrieved on July 1, 2008 from http://makerere.ac.ug/documents/policy/Makerere\%20University\%20ICT\%20Policy\%20(20052009).pdf

Masambu, P. F. (2001). The round table to discuss the establishing of a Ugandan internet exchange point (IXP) background. Retrieved on June 8, 2008 from http://www.uixp.co.ug/ucc guidelines.htm

Minges, M., Brown, W., \& Kelly, T. (2001). The Internet in an African LDC: Uganda case study. Retrieved November 9, 2006 from http://www.itu.int/ITUD/ict/cs/uganda/material/uganda.pdf 
Ministry of Works, Housing and Communication. (2003). National information and communication technology policy. Retrieved on November 10, 2009 from http://www.comminit.com/en/node/148502/308

Mwesige, P. G. (2004). Cyber elites: a survey of internet café users in Uganda. Telematics \& Informatics, 21, 83-101.

MyBroadband. (2008). Uganda's national data backbone ready. Retrieved on June 10, 2008 from http://mybroadband.co.za/news/Telecoms/3172.html

MyUganda. (2008). Welcome to myUganda - Uganda's leading internet resource. Retrieved on September 30, 2008 from www.myuganda.co.ug

Nakkazi, E. (2006). Group of Uganda ISPs to purchase bandwidth together. Retrieved on July 6, 2006 from http://www.mybroadband.co.za/nephp/?m=show\&id=2619

Olojede, D. (2004). When words could kill. Newsday, May 4. Retrieved on November 17, 2009 from http://www.pulitzer.org/archives/6922

Pilot telecenter in Uganda is successful. (2006). VOA News. Retrieved on November 17, 2009 from http://www.voanews.com/english

Press, L. I. (1997). Tracking the global diffusion of the Internet. Communications of the ACM, 40(11), 1117.

Press, L., Burkhart, G. E., Foster, W., Goodman, S. E., Wolcott, P., \& Woodard, J. (1998). An Internet diffusion framework. Communications of the ACM, 41(10), 21-26.

The Republic of Uganda. (2003). National Information and Communication Technology Policy.

SchoolNet Uganda. (2008). About SchoolNet Uganda. Retrieved on June 13, 2008 from http://schoolnetuganda.sc.ug/about-schoolnet-uganda

Ssekandi, R., \& Chen, C. (2005). Roundup: Uganda makes achievements in universal primary education. Retrieved on July 17, 2008 from http://www.redorbit.com/news/education/281998/roundup_uganda_makes_achievements_in_universal primary education/index.html

Soul Beat Africa. (2008). BOSCO: Battery operated systems for community outreach. Retrieved on December 10 from http://www.comminit.com/en/node/135220/38

State House Republic of Uganda. (2009). About the president. Retrieved on April 21, 2009 from http://www.statehouse.go.ug/profile.php?catId=8

Thomasson, J., Foster, W., \& Press, L. (2002). The diffusion of the Internet in Mexico. Latin America Network Information Center, University of Texas at Austin. Retrieved from http://www.lanic.utexas.edu/project/etext/mexico/thomasson/thomasson.pdf

Tashobya, C. K., \& Ogwal, P. O. (2004). The effort to achieve the millennium development goals in Uganda: Reaching for the sky? Health Policy and Development, 2(1), 33-39.

Tushabe, F., \& Baryamureeba, V. (2005). Cyber crime in Uganda: Myth or reality? In Tusubira Kaggwa \& Ongora, Towards an African e-index: ICT access and usage 2005

Uganda Bureau of Statistics. (2006). National statistics. Retrieved on October 10, 2006 from http://www.ubos.org/

Uganda Communications Commission. (2005). Rural communications. Retrieved on October, 2006 from http://www.ucc.co.ug/rcdf/default.php

Uganda Communication Commission (2006). Report on the survey for Internet development in Uganda. Retrieved from http://www.ucc.co.ug/internetDevptInUganda.pdf

Uganda Communication Commission. (2007). Status of the communications market. Retrieved on July 1 , 2008 from http://www.ucc.co.ug/MarketReviewDecember2007.pdf 
Uganda Communications Commission. (2008) Welcome to UCC. Retrieved on July 1, 2008 from http://www.ucc.co.ug/index.php

Uganda Communications Commission. (2009a). The Uganda Communication Commissions Act. Retrieved on April 21, 2009 from http://www.ucc.co.ug/ucaCap106LawsOfUganda.pdf

Uganda Communications Commission. (2009b). Licensed Communications Service Providers. Retrieved on April 21, 2009 from http://www.ucc.co.ug/licensing/ictOperators.php

Uganda Internet Exchange Point. (2009). Keeping local traffic local. Retrieved on Accessed December 28, 2009 from http://www.uixp.co.ug/what.htm

Ugandan Minister Knocks South Africa's Telecoms Policy and High SAT3 Prices. (2008). Business Day. Retrieved on June 302008 from http://www.balancingact-africa.com/news/back/balancingact $400 . h$ tml

United Nations Economic Commission for Africa. (2009). Uganda - Internet connectivity. Retrieved on March 26, 2009 from http://www.uneca.org/AISI/NICI/country profiles/uganda/uganinter.htm

U.S. Department of State. (2009). Background note: Uganda. Retrieved on April 21, 2009 from http://www.state.gov/r/pa/ei/bgn/2963.htm

Wahome, M. (2009). Uganda: Kampala leads in Internet use. Daily Nation on the Web, 27 October, 2009. Retrieved on November 17, 2009 from http://allafrica.com/stories/printable/200910270854.html

Wehrenfennig, D. (2006). Beyond diplomacy: Conflict management in the network society. Paper presented at the 2006 annual meeting of the American Political Science Association in Philadelphia, PA. Retrieved on November 22, 2009 from http://www.allacademic.com/meta/p151460 index.html

Wireless Federation. (2008). Mobile Internet usage growing in Uganda. Retrieved on November 17, 2009 from http://wirelessfederation.com/news/?s=mobile+Internet+usage+growing+in+uganda

World Fact Book. (2009). Uganda. Retrieved on April 21, 2009 from https://www.cia.gov/library/publications/the-world-factbook/geos/ug.html

Wolcott, P., Press, L., McHenry, W., Goodman, S., \& Foster, W. (2001). A framework for assessing the global diffusion of the Internet. Journal of the Association for Information Systems, 2(6), 1-51.

Yahoo! Groups Directory. (2009). Browse groups about Uganda. Retrieved on November 30, 2009 from http://dir.groups.yahoo.com/dir/Regional/Countries/Uganda

\section{Biographies}

Patience Akpan-Obong, who holds a PhD in Political Science (University of Alberta,

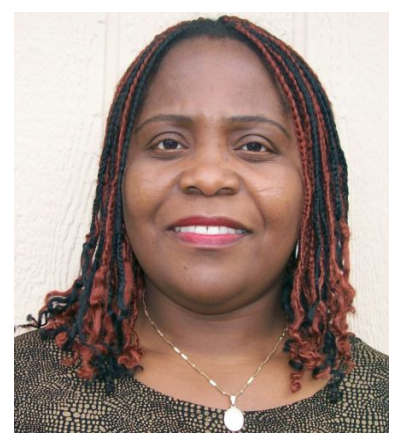
2003), is an assistant professor of government in the School of Letters and Sciences at Arizona State University. She teaches courses in science, technology and society, political science and women's studies. Her research focuses on the role of information and communication technologies in development and regional integration in Africa and Latin America. She is widely published in this area. Her recent book is Information and Communication Technologies in Nigeria: Prospects and Challenges for Development. New York: Peter D. Lang (2009). 


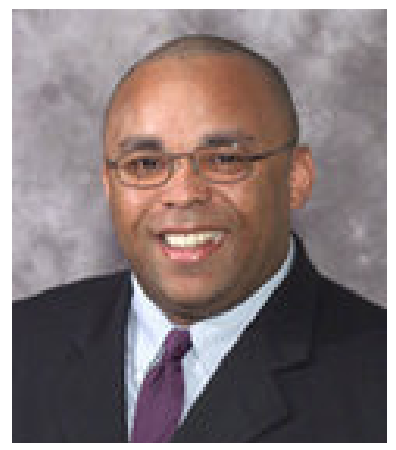

Carlos Thomas is an Assistant Professor of Management at Southern University in Baton Rouge, Louisiana. His research interests include technology in the developing world, health care supply chain management, IT governance, and E-government.

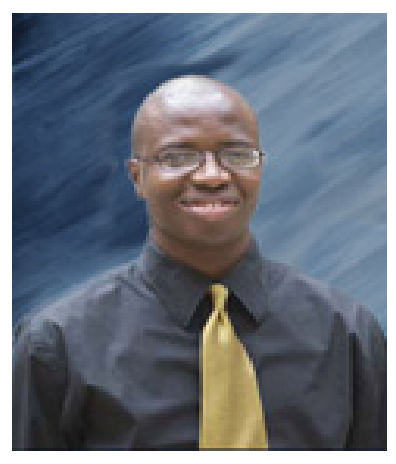

Kibily D Samake is a Doctoral Candidate at Louisiana State University. His research centers on the implications of information and communication technologies for developing countries particularly in the areas of healthcare information systems, and organizational systems. He has been published in the proceedings of the Academy of Management annual meeting, the Americas Conference on Information Systems (AMCIS) and the International Federation for Information Processing (IFIP) International Conference on Social Implications of Computers in Developing Countries.

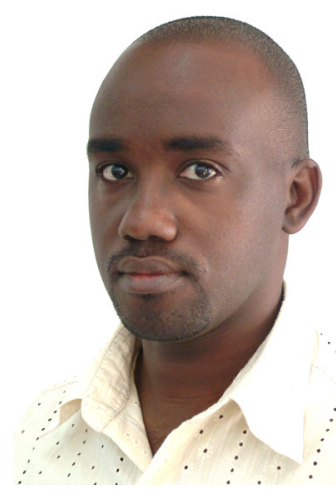

Moses Niwe is a researcher in the Department of Computer and Systems Sciences at Stockholm University/Royal Institute of Technology, Stockholm, Sweden. He is particularly interested in e-commerce and does research in the area. He won an award for "best project team" in Information Systems Engineering Innovative Project in Colombo, Sri Lanka. In addition, he facilitated and supervised several information systems modules and projects at Makerere University.

Victor W. Mbarika is on faculty in the College of Business at Southern University and

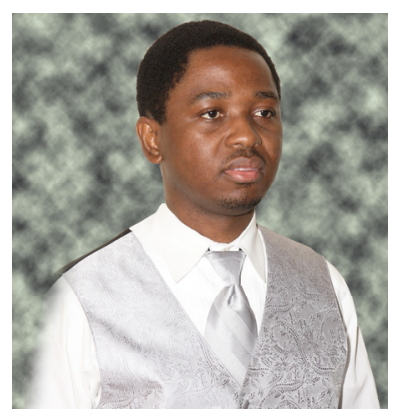
A\&M College. He is founder and executive director of the university's International Center for Information Technology and Development. He holds a B.S. in Management Information Systems from the U.S. International University, an M.S. in MIS from the University of Illinois at Chicago, and a Ph.D. in MIS from Auburn University. He has published more than 125 academic articles and five books on the general area of implementation of information and communication technologies in Africa. 